\title{
STRATEGI PENGHIDUPAN NELAYAN PEDAGANG DI TEMPAT PELELANGAN IKAN (LELONG)
}

\author{
M. Syaiful \\ Dosen Sosiologi Agama, Universitas Islam Negeri Alauddin Makassar \\ Email Korespondensi: muhammad.sayful@uin-alauddin.ac.id
}

\begin{abstract}
Abstrak. Lebih dari 30 tahun Lelong di Kota Makassar eksis sebagai lembaga perekonomian yang bergerak di bidang perdagangan sumber daya kelautan dan perikanan. Oleh karena itu, Lelong merupakan sarana yang penting bagi kelangsungan hidup masyarakat, khususnya bagi para nelayan. penelitian ini bertujuan untuk menguraikan strategi penghidupan para nelayan pedagang, dan juga menganalisis lebih mendalam tentang penerapan strategi adaptasi dalam menghadapi kerentanan finansial yang akan mengganggu kehidupan sosial ekonomi para nelayan di pesisir Lelong Kota Makassar. Jenis penelitian yang digunakan adalah deskriptif kualitatif. Penelitian ini dilaksanakan di Lelong Rajawali, Kota Makassar. Informan dalam penelitian ini berjumlah sepuluh orang dan terdiri dari nelayan pedagang, pengelola Lelong, serta pembeli ikan. Jenis data yang digunakan dalam penelitian ini, yaitu data primer dan data sekunder. Teknik pengumpulan data dilakukan dengan cara observasi, wawancara dan studi dokumen. Data primer dan data sekunder kemudian dianalisis dengan menggunakan model analisis deskriptif kualitatif, serta menguraikannya dalam bentuk naratif. Hasil penelitian menunjukkan bahwa terdapat dua faktor yang menyebabkan nelayan pedagang mengalami kerentanan finansial, yaitu meningkatnya jumlah nelayan pedagang di Lelong dan berkurangnya pembeli untuk berbelanja di Lelong. Adapun strategi penghidupan yang dilakukan oleh nelayan pedagang di Lelong adalah dilandasi oleh dua hal, yaitu pembelian tunai dan hutang. Sebagian besar nelayan pedagang lebih memilih untuk berhutang saat bertransaksi dengan nelayan penangkap ikan. Lebih lanjut, Strategi adaptasi yang dilakukan antara lain strategi konsolidasi, strategi akumulasi, dan strategi diversifikasi. Dengan dasar kesimpulan tersebut, para nelayan pedagang membutuhkan ruang aliansi perlindungan demi tercapainya sekuritas ekonomi yang berkepanjangan.
\end{abstract}

Kata Kunci:

Kerentanan Finansial; Lelong;

Nelayan Pedagang;

Strategi Adaptasi;

Strategi Penghidupan.

artikel dengan akses terbuka dibawah lisensi CC BY -4.0

DOI: https://doi.org/10.37276/sjss.v1i1.95 


\section{PENDAHULUAN}

Sulawesi Selatan merupakan salah satu daerah pesisir di Indonesia. Terdapat banyak kelompok masyarakat di Sulawesi Selatan yang mata pencaharian utamanya adalah nelayan atau menggantungkan hidupnya pada laut (K. Karmilawati \& N. Najamuddin, 2019). Salah satu daerah di Sulawesi Selatan yang menjadikan sektor kelautan dan perikanan sebagai andalan pertumbuhan ekonomi masyarakatnya adalah Kota Makassar. Bagi sebagian warga Kota Makassar, sumber daya laut berupa ikan dan hasil laut lainnya merupakan potensi ekonomi yang sangat penting bagi kehidupan mereka (M. Sayful, 2019). Begitu pula yang tinggal dan beraktivitas di kawasan Tempat Pelelangan Ikan atau masyarakat Makassar lebih familiar dengan istilah "Lelong".

Lebih dari 30 tahun Lelong di Kota Makassar eksis sebagai lembaga perekonomian yang bergerak di bidang perdagangan sumber daya kelautan dan perikanan. Oleh karena itu, Lelong merupakan sarana yang penting bagi kelangsungan hidup masyarakat, khususnya bagi para nelayan. Selain nelayan, banyak masyarakat di Kota Makassar dan sekitarnya (Gowa, Takalar, dan Jeneponto) juga menggantungkan hidupnya di Lelong. Hal ini dikarenakan banyaknya pihak yang terlibat dalam kegiatan ekonomi, antara lain nelayan yang menangkap ikan, nelayan pedagang, pengusaha rumah makan, warga sekitar, serta pihak pengelola Lelong itu sendiri. Nelayan dan pihak-pihak terkait yang berada dalam sistem perdagangan di Lelong merupakan satu kesatuan sosial ekonomi yang saling berhubungan. Selain itu, kategori sosial inilah yang kemudian berperan penting dalam kegiatan perekonomian di Lelong, Kota Makassar.

Salah satu pihak yang terus menggantungkan hidupnya di Lelong adalah mereka yang berprofesi sebagai nelayan pedagang. Sebagai nelayan pedagang, mereka dihadapkan pada situasi dan kondisi berupa tantangan yang relatif lebih besar. Apalagi bagi mereka yang tinggal di wilayah daratan kota Makassar, suka atau tidak suka harus beradaptasi dengan kondisi sosial budaya masyarakat perkotaan (M. Sayful, 2017).

Selain itu juga harus dilakukan penyesuaian berdasarkan konteks ekonomi masyarakat perkotaan yang berbeda dengan karakteristik ekonomi masyarakat pulau. Akibatnya, banyak potensi kerentanan finansial yang akan mengganggu kehidupan sosial ekonomi mereka. Oleh karena itu, para nelayan pedagang harus mewaspadai dampak yang akan timbul akibat kerentanan tersebut. Mereka harus memikirkan dan melakukan serangkaian upaya untuk memperoleh ketahanan ekonomi di tengah potensi kerentanan finansial yang mereka hadapi. Kondisi inilah yang juga menciptakan dinamika sosial ekonomi bagi para nelayan pedagang di Lelong.

Telah banyak penelitian di Indonesia yang membahas strategi adaptasi dan penghidupan pada kelompok masyarakat tertentu. Namun belum ada yang pernah meneliti strategi penghidupan para nelayan pedagang di Tempat Pelelangan Ikan. Adapun objek penelitian yang sama dimana Agus Maladi Irianto (2014) menjelaskan bahwa: 
"Tindakan sosial manusia yang terjadi dari rangkaian interaksi tersebut kemudian akan membentuk konsep jejaring sosial dan dijadikan sebagai strategi adaptasi PKL di Kota Semarang."

Dari uraian di atas dapat dipahami bahwa strategi adaptasi merupakan bentuk penyesuaian diri terhadap lingkungan sosial. Adapun perbedaan penelitian di atas dengan penelitian ini terletak pada subjek penelitiannya.

Selanjutnya menurut S. Suryadi, Ahmad Humam Hamid, \& A. Agussabti (2013), bahwa:

"Petani kopidiKecamatanKute Panang terancamkehilangan matapencaharian sebagai akibat konflik horizontal antara Pemerintahan Indonesia dengan GAM beberapa tahun lalu yang berujung pada pengambilalihan paksa lahan kopi milik warga. Selanjutnya petani kopi menerapkan strategi bertahan hidup yang dikelompokkan menjadi dua kategori, yaitu base livelihood dan livelihood diversification. Semua strategi yang dilakukan oleh petani kopi adalah untuk memenuhi kebutuhan pokoknya."

Dari uraian di atas dapat diketahui bahwa kesamaan dengan penelitian ini terletak pada kerangka analisis (strategi penghidupan). Sedangkan perbedaannya terletak pada subjek dan fokus penelitian. Penelitian tersebut tidak mengkaji strategi adaptasi dan penghidupan para petani kopi.

Lebih lanjut, menurut Wahyu Dwi Sutami (2012), bahwa:

"Banyaknya pedagang yang menjual barang dagangan sejenis di pasar tradisional menciptakan persaingan usaha dalam menjaring pembeli antar pedagang. Hal ini menuntut pedagang untuk kreatif menarik konsumen untuk meningkatkan keuntungan. Meski keuntungan yang didapat tidak besar, mereka tetap berjualan dengan membangun relasi untuk menambah keuntungan."

Dari uraian di atas dapat diketahui bahwa kesamaan dengan penelitian ini terletak pada subjek penelitiannya. Sedangkan perbedaannya terletak pada fokus penelitian dan kerangka analisis. Penelitian tersebut tidak mengkaji strategi adaptasi dan penghidupan para pedagang di pasar tradisional dalam menghadapi guncangan ekonomi.

Adapun menurut Agil Cahyo Nugroho, Bambang Hari P., \& S. Sukidin (2013), bahwa:

"Kebijakan yang ditetapkan oleh pengelola pasar mempengaruhi pedagang dalam memaksimalkan pendapatannya. Untuk itulah, para pedagang melakukan strategi bertahan hidup dengan memanfaatkan sumber daya yang ada untuk mempertahankan bisnisnya dan memaksimalkan pendapatan. Upaya yang dilakukan para pedagang tersebut dengan konsep interaksi, kerjasama, strategi kepercayaan budaya Jawa, dan diversifikasi pekerjaan."

Dari uraian di atas dapat diketahui bahwa terdapat relevansi yang besar dengan penelitian ini. Persamaannya terletak pada kerangka penelitian terkait penggunaan strategi bertahan hidup. Namun, dalam mendeskripsikan bentuk-bentuk strategi bertahan hidup, penelitian tersebut menggunakan interaksi sosial. Sehingga terlihat bahwa perbedaannya dengan penelitian ini terletak pada fokus penelitian. 
Akhirnya, dengan menggunakan setting sosial dalam menjabarkan pendahuluan di atas, maka penelitian ini bertujuan untuk menguraikan strategi penghidupan para nelayan pedagang, dan juga menganalisis lebih mendalam tentang penerapan strategi adaptasi dalam menghadapi kerentanan finansial yang akan mengganggu kehidupan sosial ekonomi para nelayan di pesisir Lelong Kota Makassar.

\section{METODE}

Jenis penelitian yang digunakan adalah deskriptif kualitatif. Penelitian ini dilaksanakan di Lelong Rajawali, Kota Makassar. Informan dalam penelitian ini terdiri dari nelayan pedagang, pengelola Lelong, dan pembeli ikan yang kebetulan berbelanja di saat penelitian sedang berlangsung. Teknik penentuan informan bersifat purposive, yaitu dipilih secara sengaja berdasarkan pengetahuan dan keterlibatannya (Ahmad Tohardi, 2019) dalam kegiatan perekonomian di Lelong. Adapun jumlah informan sebanyak sepuluh orang, antara lain yaitu:

1. Nelayan Pedagang sebanyak enam orang;

2. Pengelola Lelong sebanyak satu orang; dan

3. Pembeli sebanyak tiga orang.

Jenis data yang digunakan dalam penelitian ini, antara lain yaitu (Ismail Nurdin \& Sri Hartati, 2019):

1. Data Primer, adalah data yang bersumber dari hasil penelitian lapangan yang diperoleh melalui observasi dan wawancara; dan

2. Data Sekunder, adalah data referensi dan kepustakaan yang bersumber dari studi dokumen, buku, jurnal, artikel, dan media online.

Untuk memperoleh data yang dibutuhkan dalam penelitian ini, maka digunakan teknik pengumpulan data, yakni sebagai berikut:

1. Observasi, yakni dilakukan dengan cara melihat langsung subyek penelitian, dalam hal ini nelayan pedagang yang melakukan kegiatan perekonomiannya di Lelong;

2. Wawancara, yakni dilakukan dengan cara tanya jawab umum, kemudian dilanjutkan melalui pertanyaan-pertanyaan mendalam, diskusi, dan konfirmasi, baik secara perorangan maupun berkelompok; serta

3. Studi dokumen, yakni dilakukan dengan cara memilih secara khusus dan difokuskan pada literatur, buku, serta artikel yang membahas tentang nelayan, pasar tradisional, dan strategi penghidupan ekonomi masyarakat.

Sebagai pelengkap teknik pengumpulan data di atas, maka hasil observasi dan wawancara kemudian didokumentasikan.

Data primer dan data sekunder yang berhasil dihimpun selama berlangsungnya penelitian, kemudian disusun secara sistematik, dianalisis dengan menggunakan model analisis deskriptif kualitatif, serta menguraikannya dalam bentuk naratif. 


\section{HASIL DAN PEMBAHASAN}

\section{A. Gambaran Umum Lelong}

Tempat pelelangan ikan paling terkenal di Kota Makassar adalah Lelong Rajawali. Lelong Rajawali terletak di sebelah Barat Daya Kota Makassar, tepatnya di Jalan Rajawali. Oleh karena itu, Lelong diberi nama sesuai dengan nama jalannya. Nama Lelong sendiri diambil dari bahasa lokal Makassar yang berarti "lelang/ pelelangan". Biasanya masyarakat Makassar lebih sering menyebut istilah Lelong, ketimbang Tempat Pelelangan Ikan itu sendiri. Diperkirakan Lelong sudah ada sejak 30 tahun yang lalu dan masih bertahan, meski telah banyak mengalami renovasi dan perombakan struktur bangunan.

Secara spesifik, fungsi utama Lelong adalah sebagai prasarana pendukung bagi nelayan untuk melakukan kegiatan penangkapan ikan di laut, penanganan, pengolahan, dan pemasaran ikan hasil tangkapannya, serta sebagai tempat pengawasan kapal penangkap ikan (Restu Aji Panuntun, Abdul Rosyid, \& Imam Triarso, 2015). Berdasarkan fungsi dan pelayanan yang diberikan di Lelong, maka diharapkan produktivitas tangkapan dan penjualan hasil tangkapan para nelayan akan terus meningkat.

Sebagai fasilitas terpadu, Lelong terdiri dari perairan dan daratan serta mencakup fasilitas penangkapan ikan baik alami maupun buatan. Selain itu, Lelong merupakan pusat pengembangan ekonomi perikanan, baik dalam produksi, pengolahan, maupun pemasaran (Akhmad Solihin, M. Arsyad Alamin, \& I. Isdahartatie, 2016). Keberadaan Lelong dapat memberikan kontribusi dalam peningkatan produksi ikan, devisa negara, penciptaan lapangan kerja, peningkatan pendapatan masyarakat, peningkatan pasokan ikan segar, serta peningkatan pendapatan asli daerah (PAD). Selain itu Lelong juga memiliki peran penting dengan segala fasilitasnya sebagai penunjang bagi nelayan.

Berbagai kegiatan ekonomi masyarakat di Lelong dan sekitarnya terkait komoditas kelautan terus berlanjut. Kegiatan tersebut meliputi produksi, konsumsi, dan distribusi. Oleh karena itu, Lelong dianggap sebagai pasar tradisional yang menjual hasil laut berupa ikan dan biota laut lainnya seperti kepiting, udang, cumi-cumi, dan komoditas lainnya. Banyaknya hotel, restoran, dan rumah makan seafood yang berada di kota Makassar dan sekitarnya, sehingga menjadikan Lelong sebagai tujuan untuk membeli bahan dari menu utama mereka.

\section{B. Lelong sebagai Pasar Tradisional}

Pasar adalah tempat dimana penjual dan pembeli bertemu dan melakukan transaksi perekonomian. Berdasarkan Pasal 1 butir 1 Peraturan Presiden Republik Indonesia Nomor 112 Tahun 2007 tentang Penataan dan Pembinaan Pasar Tradisional, Pusat Perbelanjaan dan Toko Modern (selanjutnya disebut Perpres No. 112 Tahun 2007), 
menjelaskan bahwa:

"Pasar adalah area tempat jual beli barang dengan jumlah penjual lebih dari satu baikyang disebut sebagai pusat perbelanjaan, pasar tradisional, pertokoan, mall, plasa, pusat perdagangan maupun sebutan lainnya."

Selanjutnya berdasarkan Pasal 1 butir 2 Perpres No. 112 Tahun 2007, menjelaskan bahwa:

"Pasar Tradisional adalah pasar yang dibangun dan dikelola oleh Pemerintah, Pemerintah Daerah, Swasta, Badan Usaha Milik Negara dan Badan Usaha Milik Daerah termasuk kerjasama dengan swasta dengan tempat usaha berupa toko, kios, los dan tenda yang dimiliki/dikelola oleh pedagang kecil, menengah, swadaya masyarakat atau koperasi dengan usaha skala kecil, modal kecil dan dengan proses jual beli barang dagangan melalui tawar menawar."

Kegiatan perekonomian di Pasar menurut D. Damsar \& I. Indrayani (2018), yaitu:

"Merupakan tempat terjadinya proses transaksi antara pembeli dan penjual serta tempat untuk mendapatkan sarana pemenuhan kebutuhan dengan harga yang wajar."

Selain memiliki fungsi ekonomi, pasar juga memiliki peran sosial, sebagaimana menurut Geoffrey M. Hodgson dalam Pheni Chalid (2009), bahwa:

"Pasar sebagai rangkaian institusi sosial di mana banyak komoditas dengan berbagai jenis dan ukuran dipertukarkan secara teratur dan terkadang difasilitasi oleh instansi terkait."

Dengan kata lain, pasar merupakan ekspresi dari pola pertukaran dalam tatanan sosial tertentu yang menghubungkan berbagai kategori sosial, seperti hubungan sosial, jaringan, nilai dan cara, serta etika dan budaya.

Beberapa jenis pasar diklasifikasikan menurut aktivitas, lokasi dan kapasitas pelayanan, waktu aktivitas, serta status kepemilikan. Berdasarkan status kepemilikan pasar dibedakan menjadi dua, yaitu pasar pemerintah dan pasar swasta (Erna Puspita \& Dian Kusumaningtyas, 2018). Namun masyarakat lebih mengenal kedua istilah tersebut sebagai pasar tradisional dan pasar modern. Pasar tradisional yang di kelola oleh Pemerintah dengan memberikan sarana tempat usaha berupa toko, kios, los dan tenda yang dimiliki/dikelola oleh pedagang. Sedangkan pasar modern dengan status kepemilikan dan sistem pelayanan mandiri, seperti minimarket, hypermart, atau department store, serta menjual berbagai produk dalam jumlah satuan atau eceran. dari pengertian pasar tersebut, Lelong termasuk dalam kategori pasar tradisional.

\section{Kerentanan yang Dialami Nelayan Pedagang}

\section{Meningkatnya Jumlah Nelayan Pedagang}

Tingginya arus urbanisasi dan ketidakmampuan kota dalam menyediakan lapangan kerja yang memadai di sektor formal berimplikasi pada semakin 
banyaknya orang yang memulai usaha di sektor informal (Tim Peneliti AcSI-SADAR, 2009). Dari tahun ke tahun, kemacetan arus transportasi dan kepadatan pemukiman akibat pertumbuhan penduduk tidak menghentikan laju migrasi. Mengadu nasib adalah penyebab utama masyarakat Desa datang ke Kota. Namun sebagian besar dari mereka umumnya tidak memiliki latar belakang pendidikan yang memadai, sehingga dengan keterbatasan tersebut akhirnya memilih pekerjaan di sektor informal.

Pengertian sektor informal meliputi sektor produksi, distribusi, konsumsi, hingga jasa (S. Suradi, 2011). Salah satu hal yang menjadi sektor informal adalah pasar. Di pasar, seseorang dapat bekerja tanpa perlu memiliki status pendidikan yang harus dibuktikan dengan ijazah. Selain itu, modal yang dibutuhkan relatif lebih kecil. Inilah alasan mengapa pasar menjadi sumber sektor ekonomi informal. Seseorang dengan keterampilan terbatas dan latar belakang pendidikan rendah juga dapat dengan mudah mengakses pekerjaan di pasar.

Salah satu faktor yang menyebabkan semakin banyaknya nelayan pedagang di Lelong adalah lemahnya manajemen pengelola Lelong. Perencanaan dan kebijakan yang tidak melibatkan aspirasi nelayan pedagang membuat mereka luput dari kebutuhan para nelayan pedagang. Akibatnya, ketidaksesuaian kepentingan antara nelayan pedagang dan pengelola Lelong seringkali membuat nelayan pedagang menjadi korban dari segala aturan kebijakan pengelolaan pasar tradisional.

Selain itu, meningkatnya jumlah nelayan pedagang di Lelong juga karena beberapa nelayan pedagang meminta kerabatnya untuk bekerja membantu mereka berdagang. Awalnya, mereka hanya diikutsertakan untuk membantu menjual ikan di lapakan yang sama. Seiring waktu, jika mereka telah menguasai kondisi Lelong dan teknik perdagangan, para pekerja ini akan diizinkan untuk mengembangkan perdagangan mereka dengan membuka lapak sendiri. Akhirnya banyak nelayan pedagang yang kemudian menguasai beberapa areal lapak di Lelong dan mendominasi wilayah tersebut. Ketiadaan batas dan aturan yang jelas memungkinkan seorang nelayan pedagang untuk memonopoli blok tertentu di Lelong. Kondisi ini sekaligus menimbulkan keterbatasan bagi nelayan pedagang lainnya yang tidak memiliki modal yang cukup besar.

\section{Kecenderungan (Trend) Berkurangnya Jumlah Pembeli}

Hasil wawancara menunjukkan bahwa jumlah pembeli ikan yang datang ke Lelong setiap tahun semakin menurun. Apalagi saat pandemi Covid-19 yang berlangsung satu tahun belakangan ini. Hal ini disadari oleh sebagian besar nelayan pedagang yang sudah puluhan tahun melakukan aktivitas perdagangan di Lelong. Mereka menyebutkan bahwa sebelum masa pandemi Covid-19, masih banyak pembeli yang bekerja di kantor pemerintah yang berbelanja di 
Lelong. Para nelayan pedagang meyakini konsumen dari kalangan birokrasi kini lebih suka berbelanja di pasar modern. Konsumen selebihnya merupakan pelanggan tetap yang telah menjalin hubungan dagang dengan nelayan pedagang, misalnya pengusaha rumah makan atau restoran.

Penurunan pembeli di pasar tradisional umumnya juga disebabkan oleh perubahan persepsi konsumen. Menjamurnya pasar modern membuat mereka menarik perbandingan antara keduanya. Pasar modern saatini juga memberikan pelayanan hingga harga yang cenderung lebih terjangkau. Kondisi tempat juga dinilai lebih sejuk, lebih nyaman, bersih, dan praktis. Tak ketinggalan bahkan menyediakan layanan pembayaran tagihan bulanan, seperti listrik dan air, serta berbagai pembayaran payment point untuk transaksi belanja online seperti public utility, transportasi, multi finance, TV kabel, E-Commerce, dan masih banyak pilihan produk lainnya sehingga pengunjung dapat dengan mudah mencari produk yang ingin dibelinya.

Bentuk usaha pasar modern seperti Alfamart, Indomaret, Circle K, Alfamidi, dan lainnya juga telah melebarkan sayap usahanya. Gerai mereka kini telah berdiri di pemukiman padat penduduk, bahkan hingga ke gang-gang. Mereka ada dimana-mana, baik itu di pinggiran kota, kompleks permukiman, SPBU, dan hampir semua poros jalan arteri. Selain itu, beberapa pasar modern beroperasi hampir 24 jam. Dengan bekerjasama dengan produsen dan membeli barang dalam jumlah yang besar, juga akan membuat harga jual lebih murah. Menurut Ishak Salim (2013).

"Aksesibilitas ini memungkinkan pembeli tidak lagi jauh-jauh berbelanja di pasar tradisional. Sebab, pasar modern rela datang dan mendekati konsumennya. Kenyamanan dan kemudahan dalam berbelanja menjadi penyebab berubahnya pola belanja masyarakat yang dari gadde-gadde (warung barang kebutuhan rumah tangga milik warga setempat) ke minimarket."

Sementara itu, pasar tradisional diidentikkan oleh sebagian masyarakat sebagai kawasan kumuh, semrawut, becek, pengap, bau, dan sumpek. Pasar tradisional juga sering dituduh menjadi biang kemacetan karena para pedagang kerap menjual dagangannya dengan memanfaatkan sempadan jalan.

\section{Dampak Kerentanan}

Dari sekian banyak sumber kerentanan yang dihadapi para nelayan pedagang di Lelong, penurunan omzet penjualan merupakan akibat yang biasa dialami oleh sebagian besar nelayan pedagang. Nelayan pedagang di Lelong memiliki kekuatan modal yang kecil, sehingga kemampuan membeli ikan dan komoditas laut lainnya untuk dijual kembali akan sangat terbatas. Jika berbelanja dalam jumlah sedikit, maka harga pokok pembelian akan lebih mahal. Terakhir, nelayan pedagang di Lelong menetapkan harga jual yang lebih tinggi untuk 
ikan dan komoditas laut lainnya. Hal ini mengakibatkan para nelayan pedagang mulai mengurangi jumlah pesanan untuk dijual atau mulai mencari jenis dagangan baru.

Seiring dengan penurunan omset, hal ini juga akan berimplikasi pada penurunan laba, bahkan ada juga yang merugi. Biasanya kondisi ini banyak dialami oleh nelayan pedagang yang jenis dagangannya cepat busuk. Jika kondisi ini terjadi, maka nelayan pedagang akan menjual murah ikan dan komoditas laut lainnya agar bisa kembali modal. Pasalnya, uang harus terus berputar keesokan harinya. Sedangkan sebagian besar nelayan pedagang di Lelong, perekonomian rumah tangganya hanya ditopang oleh sumber pendapatan dari perdagangan ikannya.

\section{Penghidupan Para Nelayan Pedagang}

Strategi bertahan hidup (survival strategy) merupakan strategi yang dilakukan oleh nelayan pedagang dengan modal kecil dan tipe lapakan sederhana (Sam'un Mukramin, 2018). Setidaknya ada empat jenis lapakan yang dapat ditemukan di lokasi penelitian. Pertama, hanya memanfaatkan baskom atau boks untuk menampung dagangan ikan dan komoditas laut lainnya. Kedua, menggunakan meja kayu atau baja non-permanen. Ketiga, menempati meja permanen yang dibangun oleh pengelola Lelong. Dan keempat, yang sudah memiliki/menyewa bangunan los di Lelong. Jenis lapakan pertama dan kedua biasanya mengelola sumber daya yang terbatas atau dipekerjakan oleh nelayan pedagang lainnya dengan upah rendah. Sedangkan jenis lapakan ketiga dan keempat merupakan nelayan pedagang yang cenderung memiliki modal yang cukup besar.

Melalui observasi dan wawancara, strategi yang dilakukan nelayan pedagang tidak terbatas pada satu desain strategi saja, tetapi lebih dari beberapa penggabungan desain strategi. Dalam menghadapi perubahan pendapatan dan penurunan omzet penjualan, nelayan pedagang akan melakukan penyesuaian (adaptasi) untuk mempertahankan penghidupan mereka.

\section{Strategi Konsolidasi}

Strategi konsolidasi merupakan salah satu bentuk desain strategi yang dilakukan untuk memenuhi kebutuhan pokok keluarga serta menyisihkan sebagian pendapatannya untuk ditabung (Amatullah Mufidah \& R. Rijanta, 2018). Strategi konsolidasi dengan memaksimalkan pendapatan mengandung tindakan-tindakan yang telah melewati tingkat keamanan dari sekadar bertahan hidup, artinya nelayan pedagang sudah dapat memenuhi kebutuhan primernya. Strategi ini dilakukan untuk menghindari atau mengantisipasi suatu kondisi bilamana terdapat kebutuhan mendesak. Jika pendapatan menurun, maka beberapa pos anggaran harus ditekan. Jika pos tersebut masih harus dibayar karena keadaan darurat, maka mereka akan menggunakan tabungan, mengambil pinjaman, bahkan sampai menjual aset. 
Mekanisme strategi konsolidasi melalui utang merupakan strategi pendukung bagi rumah tangga. Dalam kondisi sulit, dimana pendapatan yang diperoleh tidak mencukupi untuk memenuhi kebutuhan, sistem tambahan yang dikembangkan adalah dengan berhutang atau meminta bantuan keuangan dari pihak lain. Selain menggunakan dana segar untuk membeli ikan dan komoditas laut lainnya, nelayan pedagang biasanya mendapatkan pinjaman dagangan dalam bentuk ikan dan komoditas laut lainnya. Nelayan yang menangkap ikan akan memberi sejumlah ikan dan komoditas laut lainnya kepada nelayan pedagang, dengan syarat harus dibayarkan dalam waktu yang telah ditentukan bersama. Nelayan pedagang akan melunasi pembelian ikan sesuai harga yang disepakati dengan nelayan penangkap ikan. Saling percaya adalah prinsip penting dari mekanisme semacam itu.

Dari beberapa kasus, terkadang ikan dan komoditas laut lainnya yang bersifat hutang tidak laku terjual, bahkan sebelum harga modal kembali. Sementara ikan dan komoditas laut lainnya sudah mulai membusuk, dan sudah tidak bisa lagi dijual. Jika nelayan pedagang memiliki banyak jenis ikan dan komoditas laut lainnya yang laris manis dan laku, dia bisa melakukan subsidi silang. Kerugian yang dialami dari satu jenis ikan atau komoditas laut, bisa dibayar dengan menggunakan keuntungan dari ikan dan komoditas laut lainnya. Jika tidak, maka dalam kondisi inilah mereka harus berhutang bahkan menggadaikan hingga menjual asetnya.

Menggadaikan atau menjual aset merupakan salah satu alternatif yang dipilih oleh nelayan pedagang saat menghadapi penurunan pendapatan. Menggadaikan barang memiliki prinsip yang sama dengan meminjam. Namun, prosedurnya tidak serumit meminjam dari lembaga keuangan formal atau informal. Menggadaikan barang dipilih sebagai upaya penyangga agar pemenuhan kebutuhan tidak berkurang secara drastis, serta tetap dapat membiayai kewajiban lainnya, walaupun dalam kondisi berkurangnya pendapatan. Namun, jika nelayan pedagang tidak mampu menebus barang yang digadaikan, maka barang tersebut akan dilelang.

Di sisi lain, sebagian besar nelayan pedagang tidak mampu menabung, dalam arti menempatkan keuntungannya di Bank. Dalam praktiknya, meski tidak menyimpan dalam bentuk tabungan di Bank, sebagian besar mereka melakukan investasi dengan membeli Emas. Hal ini dilakukan karena ketika mereka tibatiba membutuhkan uang tunai (fresh money), mereka dapat langsung menjual emas tersebut. Alasan sederhananya adalah bahwa emas lebih mudah dijual dibandingkan dengan aset lain seperti tanah atau lapakan perdagangan. Emas bisa dijual kapan saja, dan uangnya bisa segera dicairkan. Terlepas dari apakah uang yang diperoleh melalui penjualan di bawah harga atau tidak, intinya adalah uang dapat diperoleh tanpa harus menunggu dengan waktu yang lama. 


\section{Strategi Akumulasi}

Strategi akumulasi merupakan strategi yang dilakukan oleh nelayan pedagang dengan memanfaatkan keuntungan lebih (surplus) untuk mengembangkan usaha (Slamet Widodo, 2011). Strategi ini merupakan upaya pengakumulasian modal usaha untuk menjamin kelangsungan hidup. Nelayan pedagang yang telah mengakumulasikan modalnya, itu terlihat dari terpenuhinya kebutuhan sekunder dan tersier. Misalnya menunaikan ibadah haji.

Salah satu prestise anggota masyarakat adalah menyandang gelar haji di depan nama mereka. Itulah sebabnya orang yang menunaikan ibadah haji dan berhasil menyandang gelar ini adalah prestasi yang menunjukkan status sosial lebih dari yang lain. Dalam sosiologi, fenomena ini disebut dengan achieved status, yaitu status yang dapat dicapai oleh siapa saja dengan serangkaian usaha yang disengaja (M. Zainuddin, 2013).

Banyak nelayan pedagang menambah jenis dagangannya dalam satu lapakan sebagai upaya untuk memaksimalkan pendapatan. Dengan demikian, secara bersamaan akan meningkatkan beban dan risiko pekerjaan. Dalam kondisi seperti ini, mereka akan menyiasati dengan memanfaatkan sumber daya rumah tangga. Umumnya para nelayan pedagang ini akan mempekerjakan anggota rumah tangga yang sudah dewasa untuk membantu mereka memberikan daya dukung penghidupan.

Selain itu, pada sejumlah kasus yang ditemui, nelayan pedagang dengan lebih dari satu lapakan juga akan melakukan strategi yang sama. Mereka melibatkan pekerja yang merupakan kerabat dekat untuk membantu mereka berdagang di Lelong. Memilih mempekerjakan kerabat dekat selain karena unsur kepercayaan juga karena upah yang dibayarkan relatif lebih kecil dibandingkan mempekerjakan orang lain yang bukan kerabat. Jika mereka tidak memiliki kerabat dekat yang dapat membantu mereka bekerja, sebagian nelayan pedagang terpaksa mempekerjakan orang lain atau menyewakan lapakannya kepada nelayan pedagang lain. Semua ini dilakukan sebagai langkah untuk meningkatkan pendapatan para nelayan pedagang.

\section{Strategi Diversifikasi}

Strategi diversifikasi adalah upaya yang dilakukan dengan mencari pekerjaan selain pekerjaan utama untuk menambah pendapatan atau menganekaragamkan pekerjaan/usaha (A. Asriadin, Syaifudin Suhri Kasim, \& S. Sarpin, 2019). Hanya sedikit nelayan pedagang di Lelong yang melakukan pekerjaan tambahan. Berbeda dengan jenis mata pencaharian lainnya, seperti di sektor pertanian yang memiliki sumber pendapatan musiman. Nelayan pedagang harus melakukan aktifitasnya setiap hari di Lelong, sehingga tidak 
mungkin mereka terlibat dalam pekerjaan lain. Inilah sebabnya mengapa tidak banyak yang memiliki pekerjaan lain selain menjadi nelayan pedagang.

Oleh karena itu, jenis diversifikasi yang dilakukan oleh nelayan pedagang adalah diversifikasi produk. Umumnya jenis dagangan yang dijual tidak hanya untuk satu jenis ikan atau komoditas laut lainnya, namun ada pula yang masih konsentris. Konsentris dimaksudkan hanya untuk menjual satu jenis ikan atau komoditas laut lainnya. Misalnya, nelayan pedagang yang hanya menjual jenis ikan bandeng. Jika sudah tercampur dengan jenis ikan dan komoditas laut lainnya, maka mereka telah melakukan diversifikasi produk. Tak heran jika kita melihat para nelayan pedagang di Lelong juga menjual udang, kepiting, cumi-cumi, kerang, dan komoditas laut lainnya, bahkan beberapa nelayan pedagang menjual ikan kering. Sehingga untuk memaksimalkan keuntungan, menambah jenis ikan dan komoditas laut lainnya menjadi strategi yang memungkinkan bagi nelayan pedagang. Selain berguna untuk memaksimalkan keuntungan, diversifikasi produk membantu memudahkan nelayan pedagang untuk melakukan subsidi silang. Jika salah satu dagangannya tidak laku, dia bisa menutupinya dengan penghasilan dari jenis dagangan lainnya. Ini karena sebagian besar nelayan pedagang menghabiskan waktunya di Lelong, sebagai upaya untuk meningkatkan pendapatan mereka dan mengurangi risiko kerugian.

\section{KESIMPULAN DAN SARAN}

Berdasarkan uraian hasil dan pembahasan, maka dapat disimpulkan bahwa terdapat dua faktor yang menyebabkan nelayan pedagang mengalami kerentanan finansial, yaitu meningkatnya jumlah nelayan pedagang di Lelong dan berkurangnya pembeli untuk berbelanja di Lelong. Salah satu penyebab pembeli berkurang ialah karena menjamurnya pasar modern seperti Alfamart, Indomaret, Circle K, Alfamidi. Adapun strategi penghidupan yang dilakukan oleh nelayan pedagang di Lelong adalah dilandasi oleh dua hal, yaitu pembelian tunai dan hutang. Sebagian besar nelayan pedagang tidak memiliki modal yang besar, sehingga pembelian tunai cenderung dihindari saat berhadapan dengan nelayan penangkap ikan. Jika harus melakukan pembayaran tunai tentunya tidak banyak komoditas laut yang bisa dijual, sehingga penghasilannya juga akan kecil. Oleh karena itu, banyak dari mereka lebih memilih untuk berhutang. Biasanya komoditas laut yang dibayar langsung adalah jenis seafood karena bisa bertahan lama, sehingga jangka waktu penjualannya juga relatif lebih panjang. Umumnya, strategi nelayan pedagang adalah mengambil hutang atas komoditas laut di beberapa nelayan penangkap ikan dengan kepemilikan kapal yang besar. Jadi, dengan berbagai jenis komoditas laut yang diperdagangkan, nelayan pedagang akan dengan mudah melakukan subsidi silang pembayaran utang. Oleh karena itu, dengan pengaturan yang tepat, mereka juga bisa menyisihkan keuntungannya dalam sehari. Namun, jika mereka tidak mendapatkan keuntungan dalam sehari, itu akan memberikan kerentanan finansial yang akan mengganggu kehidupan rumah tangganya. Dalam menghadapi perubahan pendapatan 
dan penurunan omzet penjualan, nelayan pedagang akan melakukan strategi adaptasi untuk mempertahankan penghidupan mereka. Strategi adaptasi yang dilakukan tidak terbatas pada satu desain strategi saja, tetapi lebih dari beberapa penggabungan desain strategi, antara lain strategi konsolidasi, strategi akumulasi, dan strategi diversifikasi. Dengan dasar kesimpulan tersebut, para nelayan pedagang membutuhkan ruang aliansi perlindungan demi tercapainya sekuritas ekonomi yang berkepanjangan.

\section{REFERENSI}

A. Asriadin, Syaifudin Suhri Kasim, \& S. Sarpin. (2019). Strategi Bertahan Hidup Nelayan Tradisional Suku Bajo dalam Pemenuhan Kebutuhan Keluarga (Studi di Desa Mantigola Kecamatan Kaledupa Kabupaten Wakatobi). Jurnal Neo Societal, Universitas Halu Oleo Kendari, 4(2), hlm. 718-728.

Agil Cahyo Nugroho, Bambang Hari P., \& S. Sukidin. (2013). Strategi Survival Pedagang Tradisional pada Pasar Relokasi Dinoyo Kota Malang. Artikel Penelitian Mahasiswa, Universitas Jember, hlm. 1-6.

Agus Maladi Irianto. (2014). Strategi Adaptasi PKL Kota Semarang: Kajian Tentang Tindakan Sosial. Komunitas: International Journal of Indonesian Society and Culture, Universitas Negeri Semarang, 6(1), hlm. 70-90. doi: https://doi. org/10.15294/komunitas.v6i1.2938

Ahmad Tohardi. (2019). Pengantar Metodologi Penelitian Sosial + Plus. Pontianak: Tanjungpura University Press.

Akhmad Solihin, M. Arsyad Alamin, \& I. Isdahartatie. (2016). Penguatan Kelembagaan TPI dalam Mewujudkan Perikanan Berkelanjutan dan Berkeadilan. Risalah Kebijakan Pertanian dan Lingkungan: Rumusan Kajian Strategis Bidang Pertanian dan Lingkungan, Institut Pertanian Bogor, 3(3), hlm. 205-215. doi: http://dx.doi. org/10.20957/jkebijakan.v3i3.16253

Amatullah Mufidah \& R. Rijanta. (2018). Strategi Penghidupan Masyarakat Nelayan di Kawasan Pesisir Dusun Pantai, Desa Batu Belubang, Bangka Tengah. Jurnal Bumi Indonesia, Universitas Gadjah Mada, 7(4), hlm. 1-11.

D. Damsar \& I. Indrayani. (2018). Pengantar Sosiologi Pasar. Jakarta: Kencana Prenada Media Group.

Erna Puspita \& Dian Kusumaningtyas. (2018). Manajemen Laba: Laba pada Pedagang Tradisional dengan Sudut Pandang Fenomenologi. Majalah Ekonomi, Universitas PGRI Adi Buana Surabaya, 23(2), hlm. 228-239.

Ishak Salim. (2013). Tsunami Minimarket Tenggelamkan Pedagang Kecil di Makassar. Social Justice Magazine, Indonesia Social Justice Network, 3, hlm. 25-28.

Ismail Nurdin \& Sri Hartati. (2019). Metode Penelitian Sosial. Surabaya: Media Sahabat Cendekia.

K. Karmilawati \& N. Najamuddin. (2019). Masyarakat Nelayan Kampung Sicini Arungkeke, Jeneponto 2014-2017. Pattingalloang: Jurnal Pemikiran Pendidikan dan Penelitian Kesejarahan, Universitas Negeri Makassar, 6(2), hlm. 110-122. doi: https://doi.org/10.26858/pattingalloang.v6i2.12149 
M. Sayful. (2017). Kekerasan Kolektif di Perkotaan: Konstruksi dan Representasi Maskulinitas dalam Budaya Masyarakat Makassar. Etnosia: Jurnal Etnografi Indonesia, Universitas Hasanuddin, 2(1), hlm. 95-116.

M. Sayful. (2019). Interaksi Sosial dan Reproduksi Nilai Budaya Masyarakat Nelayan di Pelabuhan Paotere Kota Makassar. Sosioreligius: Jurnal Ilmiah Sosiologi Agama, Universitas Islam Negeri Alauddin Makassar, 4(2), hlm. 42-60.

M. Zainuddin. (2013). Haji dan Status Sosial: Studi tentang Simbol Agama di Kalangan Masyarakat Muslim, UIN Maulana Malik Ibrahim Malang. El Harakah: Jurnal Budaya Islam, Universitas Islam Negeri Maulana Malik Ibrahim Malang, 15(2), hlm. 169-184. doi: http://dx.doi.org/10.18860/el.v15i2.2764

Peraturan Presiden Republik Indonesia Nomor 112 Tahun 2007 tentang Penataan dan Pembinaan Pasar Tradisional, Pusat Perbelanjaan dan Toko Modern.

Pheni Chalid. (2009). Sosiologi Ekonomi. Jakarta: Center for Social Economics Studies (CSES) Press.

Restu Aji Panuntun, Abdul Rosyid, \& Imam Triarso. (2015). Analisis Tingkat Pemanfaatan dan Kebutuhan Fasilitas Fungsional Pelabuhan Perikanan Nusantara (PPN) Pekalongan. Journal of Fisheries Resources Utilization Management and Technology, Universitas Diponegoro, 4(2), hlm. 9-18.

S. Suradi. (2011). Peranan Sektor Informal dalam Penanggulangan Kemiskinan. Sosio Informa, Kementerian Sosial Republik Indonesia, 16(3), hlm. 221-234.

S. Suryadi, Ahmad Humam Hamid, \& A. Agussabti. (2013). Strategi Bertahan Hidup Petani Kopi Pasca Konflik (Studi Kasus di Kecamatan Kute Panang Kabupaten Aceh Tengah). Jurnal Agrisep, Universitas Syiah Kuala, 14(1), hlm. 44-53.

Sam'un Mukramin. (2018). Strategi Bertahan Hidup: Masyarakat Pesisir Suku Bajo di Kabupaten Kolaka Utara. Walasuji: Jurnal Sejarah dan Budaya, Balai Pelestarian Nilai Budaya Makassar, 9(1), hlm. 175-185. doi: https://doi.org/10.36869/wjsb. v9i1.29

Slamet Widodo. (2011). Strategi Nafkah Berkelanjutan bagi Rumah Tangga Miskin di Daerah Pesisir. Makara Hubs-Asia (Human Behavior Studies in Asia), Universitas Indonesia, 15(1), hlm. 10-20.

Tim Peneliti AcSI-SADAR. (2009). "Studi Etnografi dan Observasi Pasar-Pasar Lokal di Tengah Pertumbuhan Pusat Perbelanjaan dan Toko Modern di Kota Makassar". Laporan Penelitian. Kerjasama antara Active Society Institute (AcSI) dengan Persaudaraan Pedagang Pasar Terong (SADAR), Makassar.

Wahyu Dwi Sutami. (2012). Strategi Rasional Pedagang Pasar Tradisional. Biokultur, Universitas Airlangga, 1(2), hlm. 127-148.

\footnotetext{
I M. Sayful. (2020). Strategi Penghidupan Nelayan Pedagang di Tempat Pelelangan Ikan I (Lelong). SIGn Journal of Social Science, CV. Social Politic Genius (SIGn), 1(1), hlm. 1-14. । I doi: https://doi.org/10.37276/sjss.v1i1.95
} 